\title{
MENINGKATKAN HASIL BELAJAR KERJA BANGKU
}

\author{
Mochammad Sukarjo \\ e-mail: asukardjo@yahoo.com \\ Universitas Negeri Jakarta
}

\begin{abstract}
Abstrak: Penelitian ini bertujuan untuk mengetahui hubungan antara berpikir induktif dan sikap atas profesi teknisi secara terpisah-pisah dan secara bersama-sama terhadap hasil belajar mata latihan kerja bangku. Penelitian yang dilakukan di SMK Negeri, Jakarta Timur, DKI Jakarta, dalam tahun pelajaran 2009/2010 ini menggunakan metode survei terhadap 75 siswa/i kelas II sebagai sampel penelitian yang dipilih secara acak sederhana. Hasil penelitian menunjukkan, terdapat hubungan positif antara variabel bebas (berpikir induktif dan sikap terhadap profesi teknisi), baik secara sendiri-sendiri, maupun secara bersama-sama terhadap variabel terikat (hasil belajar kerja bangku). Penelitian ini juga mengidentifikasi implikasi hasil penelitian ini serta memberikan saran tidak lajut.
\end{abstract}

Kata kunci: hasil belajar, berpikir induktif, sikap, profesi teknisi.

\section{IMPROVING LEARNING ACHIEVEMENT FOR BENCH WORK STUDY}

\begin{abstract}
The objective of this research is to determine the relationships between inductive thinking (X1) and student vocational attitude toward technician's profession (X2) individually and simultanously and learning achievement $(Y)$ in bench work subject. The research conducted in State Vocational High School in East Jakarta, in the school year of 200/2010 proved the positive relationships between the independent variables (X1 and X2, individually and simultanously) and the independent variable $(Y)$. Based on the reseach findings, this research identified some implications and give a number of suggestions to follow up.
\end{abstract}

Keywords: learning achievement, inductive thinking, student vocational attitude, technician's profession

\section{PENDAHULUAN}

Di era informasi, seorang pekerja harus memiliki kemampuan dan profesionalisme, serta kinerja yang tinggi agar dapat bersaing dengan bangsa-bangsa lain yang ada di belahan bumi ini. Slamet (1991: 1) mengatakan untuk dapat bersaing secara internasional, diperlukan keuggulan-keunggulan baik secara kooperatif maupun kompetitif. Oleh karena itu, lulusan sekolah, terutama Sekolah Menengah Kejuruan (SMK) harus mempunyai kemampuan, keterampilan, sikap, dan motivasi yang kuat dari dalam dirinya, sehingga keprofesionalismeannya tidak diragukan.

Kedudukan dan peran pendidikan SMK tercantum dalam undang-undang pendidikan nasional, bahwa tujuan utama pendidikan kejuruan adalah mempersiapkan peserta didik untuk dapat bekerja dalam bidang tertentu (UU RI No. 20 Tahun 2003 tentang Sistem Pendidikan Nasional 2003: 43). Sejalan dengan tujuan tersebut, Schhipers mengatakan tujuan pendidikan kejuruan adalah untuk membekali siswa agar memiliki kompetensi perilakud_alam bidang kejuruan tertentu sehingga yang bersangkutan mampu bekerja demi masa depan dan untuk kesejahteraan bangsa (Schhipers \& Patratama, 1994: 19). Untuk dapat mencapai tujuan tersebut, SMK masih menghadapi berbagai hambatan, baik internal maupun eksternal, sehingga belum dapat menjamin menghasilkan lulusan SMK yang memiliki kualitas seperti yang diharapkan oleh dunia kerja.

Isu di berbagai media masa menyebutkan bahwa unjuk kerja lulusan sekolah kejuruan umumnya rendah. Lulusan SMK belum dapat dilepas langsung menghadapi sejumlah mesin dan sarana bantu produksi (Syafrudi, 1996: 66).

Banyak upaya yang telah dilakukan untuk meningkatkan kualitas dan mutu SMK, seperti penyesuaian kurikulum dengan dunia kerja, peningkatan kemampuan guru, peningkatan sarana dan prasarana, peningkatan dana oprasional melalui berbagai sumber dana, serta peningkatan peningkatan sekolah (Syafrudi, 1996: 65). Oleh karena itu, perlu adanya telaah kepustakaan secara teoretis dan penelitian yang mendalam mengenai faktor-faktor yang mempengaruhi kualitas dan kemampuan seorang lulusan SMK, terutama kajian yang berkenaan dengan sikap siswa SMK terhadap profesi teknisi, kemampuan berpikir induktif, dan penguasaan mata diklat kerja bangku.

\section{Rumusan Masalah}

Rumusan masalah penelitian ini: (1) Apakah ter- 
dapat hubungan antara kemampuan berpikir induktif siswa dengan hasil belajar kerja bangku? (2) Apakah terdapat hubungan antara sikap siswa SMK terhadap profesi teknisi dengan hasil belajar kerja bangku? (3) Apakah terdapat hubungan antara, kemampuan berpikir induktif, sikap siswa terhadap profesi teknisi secara bersama-sama dengan hasil belajar kerja bangku?

\section{Kajian Teori}

a. Hakikat Hasil Belajar Kerja Bangku

Hasil belajar mata pelajaran kerja bangku di SMK pada dasarnya adalah kemampuan seorang siswa terhadap keterampilan dasar teknik. Sedangkan istilah "kemampuan" mengarah kepada kapabilitas belajar dan merupakan hasil belajar seseorang (Gagne, 1985:46-69). Kemampuan adalah pengorganisasian hasil belajar dan pengalaman yang umumnya terdapat dalam keterampilan motorik (Gagne, Briggs, \& Wager, (1992: 107).

Untuk mempelajari keterampilan motorik perlu pentahapan-pentahapan sesuai dengan tingkatnya. Ada tujuh tingkatan klasifikasi domain psikomotor yaitu: (1) Perception (interpreting), (2) Set (preparing), (3) Guided Response (learning), (4) Mechanism (habituating), (5) Complex overt response (performing), (6) Adaptation (modifying) dan (7) Origination (creating). (Harrow, 1972: 27).

Hasil analisis kebutuhan di lapangan untuk bidang elektronik membutuhkan penguasaan pengetahuan dan keterampilan dasar rangkaian elektronik serta peralatan elektronik. (Tranggangon, 1998: 1). Kebutuhan di lapangan yang harus dikuasai baik oleh teknisi mekanis maupun teknisi elektronika, semuanya merupakan mata pelajaran dasar, baik tentang pengetahuan maupun tentang keterampilan, sikap termasuk di dalamnya keselamatan kerja. Aspek dasar pengetahuan dan keterampilan, sikap serta keselamatan kerja sangat ditanamkan di dalam mata pelajaran kerja bangku (keterampilan dasar).

Semua kebutuhan yang dibutuhkan di lapangan, terutama bagi teknisi elektronika mengenai penguasaan pengetahuan dan keterampilan dasar rangkaian elektronik serta peralatan elektronik diajarkan pada mata pelajaran keterampilan dasar teknik di SMK pada rumpun mata pelajaran kerja mekanis elektro. Butler (1979: 16) mengatakan kemampuan seseorang dalam belajar yang sangat berpengaruh di antaranya adalah pengetahuan atau keterampilan yang dikuasai sebelumnya yang berhubungan dengan materi khusus yang telah dipelajari.

b. Hakikat Kemampuan Berpikir Induktif

Proses pemikiran merupakan suatu pergerakan mental dari suatu hal ke hal yang lain, dari proposisi yang satu ke proposisi yang lainnya, dari apa yang sudah diketahui ke hal yang belum diketahui (Poepoprodjo, 1987:174). Sedangkan berpikir merupakan proses perubahan informasi dari data yang ada yang dilakukan oleh otak sebagai alatnya (De Bono, 1971: 43).

Penalaran induktif terkait dengan empiris, di mana paham empirisme menyatakan bahwa faktafakta yang terungkap lewat pengalaman manusia merupakan sumber kebenaran (Suriasumantri, 1998: 45). Pengalaman yang dialami manusia yang menjadi sumber kebenaran, merupakan ilmu bagi manusia tersebut. Titik tolak ilmu pada tahap yang paling permulaan adalah pengalaman. (Suriasumantri, 1989: 92).

Berpikir induktif adalah cara berpikir menarik kesimpulan yang umum dari kasus yang bersifat individual (Suriasumantri, 1998: 48). Karakteristik alami dari suatu argumen induktif adalah kesimpulan yang diambil dari suatu argumen mengikuti premispremis dari agumen-argumen itu sendiri, sehingga kesimpulan yang tidak diambil tidak mungkin salah.

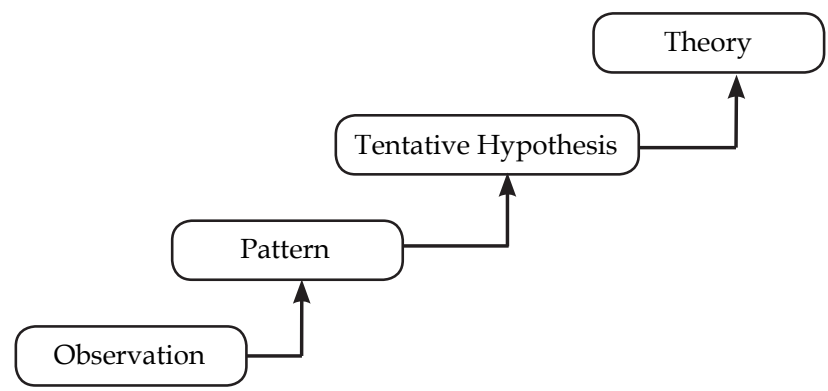

Gambar 1. Inductive Thinking

(Diambil dari Research Methods Knowledge Base. 2nd edition, 1999)

Dalam pemikiran induktif, kita mulai dari pengamatan dan pengukuran yang khusus, selanjutnya dengan mendeteksi pola dan sifat yang beraturan, kemudian rumusan hipotesis yang tentatif yang dapat digali dan akhirnya mengembangkan beberapa kesimpulan yang umum atau teori (Wiliam, 1999, 1) seperti gambar 1.

Berpikir Induktif dapat dijabarkan dalam tiga tahap yaitu: (1) memahami dan mengerti pengamatan atau keadaan informasi, (2) membentuk suatu hipotesis yang dapat menggambarkan informasi di atas dalam hubungannya dengan pengetahuan umum seseorang, serta (3) mengevaluasi validitas kesimpulan yang telah diperkaya. (Laird, Philip,1993: 1)

Dari uraian di atas, dapat ditarik kesimpulan bahwa kemampuan berpikir empiris yang dicerminkan dengan berpikir induktif adalah kemampuan siswa dalam mengambil kesimpulan secara umum dari kasus-kasus yang dijumpai atau dari hal-hal yang khusus. 
c. Sikap Terhadap Profesi Teknisi

Sikap didefinisikan sebagai kesiapan mental berdasarkan pengalaman terkait yang mempengaruhi respon setiap individu terhadap suatu objek (Oskamp,1977:9). Ahli lain mengatakan sikap adalah suatu sistem yang menetap dalam diri individu berupa penilaian positif dan negatif, yakni suatu kecenderungan untuk menyetujui atau menolak. (Krech \& Crutchfield, 1962: 177). Thurstone mengatakan definisi sikap ada 4 yaitu: (1) sikap adalah yang mempengaruhi terhadap objek psiologis, (2) penilaian terhadap objek psiko-logis, (3) suka dan tidak suka terhadap objek psikologis, dan (4) sikap adalah pandangan positif atau negatif terhadap objek psikologis.

Dari keempat definisi sikap di atas, maka yang terlibat dalam diri seseorang dapat berupa pikiran, perasaan dan juga afeksi. Hal tersebut sejalan dengan yang dikatakan Krech yang mengatakan sikap mempunyai tiga komponen yaitu: komponen kognisi, afeksi, dan konasi. (Krech, Crutchfield,\& Ballachey, 1962: 10). Ada 4 faktor yang dapat menentukan dalam pembentukan sikap seseorang, yaitu: (1) keinginan, (2) informasi, (3) hubungan dalam kelompok, dan (4) kepribadian seseorang. (Krech, Crutchfield,\& Ballachey, 1962: 180).

Salah satu dari sekian banyak objek sikap, diambil tentang profesi teknisi. Secara umum, profesi diartikan sebagai suatu pekerjaan yang memerlukan pendidikan lanjut di dalam ilmu pengetahuan dan teknologi yang digunakan sebagai perangkat dasar untuk diimplementasikan dalam kegiatan yang bermanfaat (Sardiman, 1990: 131). Selanjutnya dikatakan bahwa pekerjaan profesional akan senantiasa menggunakan teknik dan prosedur yang berpijak pada landasan intelektual yang harus dipelajari secara sengaja, terencana, dan kemudian dipergunakan demi kemaslahatan orang lain.

Teknisi adalah orang yang mempunyai keahlian untuk suatu tingkat pekerjaan tertentu yang akan mem-perbaiki suatu produk atau pelayanan (service) (AECT, 1979: 28). Pekerjaan seorang teknikus tidak hanya sekedar kebiasaan (habit) tetapi lebih luas dari itu, memerlukan pengetahuan, sikap dan keterampilan dalam menetapkan suatu langkah untuk mendeteksi suatu gejala yang terjadi dari suatu peralatan dan kemudian memecahkan masalah-masalah yang telah diketahui. Bidang keteknikan yang dihubungkan dengan training membutuhkan pengetahuan atau informasi yang mendasar pada penampilan khusus yang dibutuhkan (Larson, 1972: 26). Butler menempatkan posisi teknisi (dalam melacak kerusakan) pada tingkat teratas dari susunan pekerjaan (job hierarchy) untuk elektronika. Selanjutnya dikatakan oleh Larson bahwa pertumbuhan yang cepat dari industri dan inovasi teknologi mengharuskan penyesuaian dengan situasi kebutuhan setiap perusahaan dan teknisi secara komprehensip dan memahami lebih cermat dari ilmu pengetahuan dan teknologi yang meliputi dalam penampilan tugas.

Dari uraian di atas dapat disimpulkan bahwa sikap dapat menentukan penilaian seseorang terhadap suatu objek. Sedangkan profesi teknisi adalah suatu keahlian dalam pekerjaan tertentu yang akan memperbaiki suatu produk atau service.

\section{Kerangka Berpikir}

1. Hubungan Antara Kemampuan Berpikir Induktif Siswa X1 dengan Hasil Belajar Kerja Bangku Y

Kemampuan berpikir induktif merupakan proses berpikir untuk mengambil kesimpulan umum dari hal-hal yang khusus. Orang yang memiliki kemampuan berpikir induktif, rasionalismenya akan kuat, karena hal ini didapat dari pengalaman-pengalaman individu. Semua kemampuan yang diperolehnya, baik dari bangku sekolah maupun pengalaman yang diperoleh dari luar, seperti pengalaman praktik dari dunia industri, akan menjadikan bekal yang berharga bagi siswa untuk dapat mengambil kesimpulan secara umum dari apa yang pernah dialami. Oleh karena itu, diharapkan dengan kemampuan berpikir induktif siswa akan memiliki penguasaan kemampuan keterampilan dasar teknik yang baik.

Dari uraian di atas menunjukkan adanya hubungan positif antara kemampuan berpikir induktif siswa SMK dengan kemampuan keterampilan dasar teknik. Semakin tinggi kemampuan berpikir induktif seseorang, maka akan semakin tinggi pula kemampuan keterampilan dasar tekniknya, demikian pula sebaliknya.

2. Hubungan Antara Sikap Siswa Terhadap Profesi Teknisi X2 dengan Hasil Belajar Kerja Bangku Y

Seseorang menyukai atau menolak suatu objek didasari pada pengetahuan dan informasi yang dimiliki orang tersebut terhadap objek yang disenangi dan ditolaknya. Apabila seseorang menyenangi pekerjaan teknisi, maka orang tersebut akan berusaha mencari tahu dan informasi hal-hal yang berhubungan dengan profesi teknisi. Hal ini membawa konsekuensi orang tersebut akan bekerja mengikuti rambu-rambu yang telah ada atau sesuai dengan kriteria seorang teknisi. Ini berarti bahwa kecenderungan untuk melakukan suatu kegiatan dengan benar ditentukan oleh rasa senang, pengetahuan yang dimiliki siswa, serta sesuai tidaknya dengan harapan yang ingin dicapai siswa.

Dengan demikian, diduga bahwa apabila si- 
kap siswa SMK terhadap profesi teknisi baik, maka diharapkan kemampuan keterampilan dasar keteknikannya akan baik. Oleh karena itu, dapat dikatakan bahwa sikap siswa terhadap profesi teknisi mempunyai hubungan positif dengan kemampuan keterampilan dasar keteknikan.

3. Hubungan Antara Kemampuan Berpikir Induktif, Sikap Siswa Terhadap Profesi Teknisi Secara Bersama-Sama dengan Hasil Belajar Kerja Bangku

Dari uraian kerangka berpikir yang menyatakan bahwa semakin tinggi kemampuan berpikir induktif seseorang, maka akan semakin tinggi pula hasil belajar kerja bangku. Oleh karena itu, diduga terdapat hubungan positif antara kemampuan berpikir induktif dengan hasil belajar kerja bangku. Selanjutnya apabila siswa telah memilih pekerjaan teknisi sebagai profesinya, maka diduga bahwa siswa tersebut telah memiliki pengetahuan dan senang terhadap pekerjaan teknisi. Dengan demikian, dapat diduga bahwa apabila sikap siswa SMK terhadap profesi teknisi baik, maka diharapkan hasil belajar kerja bangku juga akan baik

Dari penjelasan di atas dapat ditarik kesimpulan bahwa dengan dengan kemampuan berpikir induktif yang baik serta ditambah dengan sikap yang baik pula terhadap profesi teknisi, maka semua ini secara bersama-sama diharapkan akan menghasilkan hasil belajar kerja bangku yang baik pula. Oleh karena itu, dapat diduga bahwa kemampuan berpikir induktif dan sikap siswa terhadap profesi teknisi secara bersama-sama memiliki hubungan positif dengan hasil belajar kerja bangku.

\section{Pengajuan Hipotesis}

Hipotesis penelitian: (1) terdapat hubungan positif antara kemampuan berpikir induktif siswa $X_{1}$ dengan hasil berlajar kerja bangku Y(2) Terdapat hubungan positif antara sikap siswa SMK terhadap profesi teknisi $\mathrm{X}_{2}$ dengan hasil berlajar kerja bangku Y(3) Terdapat hubungan positif antara kemampuan berpikir induktif dan sikap siswa terhadap profesi teknisi secara bersama-sama dengan hasil berlajar kerja bangku Y.

\section{METODE PENELITIAN}

\section{Jenis Penelitian}

Berdasarkan pradigmanya, penelitian ini termasuk dalam penelitian positivistik atau penelitian kuantitatif. Metode penelitian yang digunakan adalah survei dengan analisis korelasi.

\section{Waktu dan Tempat Penelitian}

Penelitian ini dilakukan di SMKN Jakarta Timur Jurusan Elektronika DKI Jakarta pada tahun ajaran 2009/2010.

\section{Prosedur Penelitian}

a. Sumber Data

Populasi penelitian ini seluruh siswa kelas II Jurusan Elektronika SMKN Jakarta Timur DKI Jakarta. Sampel penelitian sebanyak 75 siswa yang diambil dengan cara acak sederhana (simple Random Sampling). b. Teknik Analisis Data

Teknik analisis data pada penelitian ini menggunakan Analisis Varian dan Uji F.

\section{HASIL DAN PEMBAHASAN}

\section{Hasil Penelitian}

Pertama, hubungan antara berpikir induktif dengan hasil belajar kerja bangku diperoleh bentuk hu-bungan kedua variabel tersebut dengan persamaan $\mathrm{Y}=11,401+0,348 \mathrm{X}_{1}$

Untuk mengetahui keberartian persamaan regresi dilakukan uji $\mathrm{F}$ yang hasilnya dapat dilihat pada Tabel 1.

Tabel 1.Analisis varian untuk regresi $Y$ atas $X_{1}$ dengan persamaan: $Y=11,401+0,348 X_{1}$

\begin{tabular}{|c|c|c|c|c|c|c|}
\hline $\begin{array}{l}\text { Sumber } \\
\text { Varians }\end{array}$ & $\mathrm{dk}$ & JK & KT & $\mathrm{F}_{\text {hitung }}$ & \multicolumn{2}{|c|}{$\mathrm{F}_{\text {tabel }}$} \\
\hline Total & 75 & 21798 & 21798 & & $(5 \%)$ & $(1 \%)$ \\
\hline $\begin{array}{l}\text { Regresi (a) } \\
\text { Regresi (b/a) } \\
\text { Sisa }\end{array}$ & $\begin{array}{l}1 \\
1 \\
73\end{array}$ & $\begin{array}{l}20966,88 \\
69,61 \\
761.51\end{array}$ & $\begin{array}{l}20966,88 \\
69,61 \\
10,432\end{array}$ & $6,67^{*}$ & 3,37 & 6,695 \\
\hline $\begin{array}{l}\text { Tuna Cocok } \\
\text { Galat }\end{array}$ & $\begin{array}{l}10 \\
63\end{array}$ & $\begin{array}{l}116,242 \\
646,07\end{array}$ & $\begin{array}{l}11,624 \\
10,242\end{array}$ & $1,135^{\mathrm{ns}}$ & 1,98 & 2,61 \\
\hline
\end{tabular}

Keterangan:

* = Regresi signifikan pada $\alpha=0,05\left(\mathrm{~F}_{\mathrm{h}}=6,67>\mathrm{F}_{\mathrm{t}}=3,37\right)$

Regresi tidak signifikan pada $\alpha=0,01\left(\mathrm{~F}_{\mathrm{h}}=6,67<\mathrm{F}_{\mathrm{t}}=6,695\right)$

$\mathrm{ns}=$ Regresi berbentuk linear $\left(\mathrm{F}_{\mathrm{h}}=0,135<\mathrm{F}_{\mathrm{t}}=1,98\right)$

$\mathrm{dk}=$ derajat kebebasan

$\mathrm{JK}=$ Jumlah kuadrat

$\mathrm{KT}=$ Kuadrat tengah

Dari tabel 1 di atas, diketahui harga $F_{\text {hitung }}$ sebesar 6,67, sedangkan $\mathrm{F}_{\text {tabel }}$ pada $\alpha=0,05$ sebesar 3,37. Karena $F_{\text {hitung }}>F_{\text {tabel }}\left(F_{h}=6,67>F_{t}=3,37\right)$, maka dapat disimpulkan bahwa koefisien arah regresi $Y$ atas $X_{1}$ "signifikan". Untuk uji linearitas diperoleh $\mathrm{F}_{\mathrm{h}}=0,135<\mathrm{F}_{\text {tabel }}=1,98$ pada $\alpha=0,05$, dikatakan regresi linear. Dengan demikian persamaan regresi $\mathrm{Y}=$ $11,401+0,348 X_{1}$ dapat digunakan untuk memprediksi variabel terikat $Y$ dengan variabel bebas $X_{1}$. Artinya, setiap kenaikan satu-satuan $X_{1}$, akan terjadi kenaikan terhadap $Y$ sebesar 0,348 satuan pada konstanta 11,401.

Kekuatan hubungan antara $X_{1}$ dengan $Y$ yaitu $\mathrm{ry}_{1}=0,289$ dan uji keberartian koefisien korelasi dengan uji $\mathrm{t}$ didapat $\mathrm{t}_{\text {hitung }}=2,4711$. $\mathrm{T}_{\text {tabel }}$ dengan $\mathrm{dk}=74$ pada 0,05 didapat nilai $t=1,66$. Karena $t_{\text {hitung }}=2,4711>$ $\mathrm{t}_{\text {tabel }}=1,66$, maka dapat disimpulkan terdapat hubungan positif antara pengetahuan keterampilan dasar 
teknik dengan berpikir induktif.

Koefisien determinasi antara $\mathrm{Y}$ dengan $\mathrm{X} 1$ yaitu sebesar $\alpha=0,0835$. Artinya 8,35\% variasi yang terjadi pada hasil belajar kerja bangku dapat dijelaskan oleh kemampuan berpikir induktif dengan persamaan regresi $Y=11,401+0,348 X_{1}$.

Kedua, hubungan antara sikap siswa terhadap profesi teknisi dengan pengetahuan keterampilan dasar teknik diperoleh bentuk hubungan kedua variabel tersebut dengan persamaan regresi yaitu $Y=-6,139$ $+0,221 X_{2^{\prime}}$ yang hasilnya dapat dilihat pada Tabel 2 .

Tabel 2. Analisis Varian Untuk Regresi $Y$ atas $X_{2}$ dengan persamaan: $Y=-6,193+0,221 X_{2}$

\begin{tabular}{|c|c|c|c|c|c|c|}
\hline $\begin{array}{l}\text { Sumber } \\
\text { Varians }\end{array}$ & $\mathrm{dk}$ & JK & $\mathrm{KT}$ & $F_{\text {hitung }}$ & \multicolumn{2}{|c|}{$F_{\text {tabel }}$} \\
\hline Total & 75 & 21798 & 21798 & & $(5 \%)$ & (1\%) \\
\hline $\begin{array}{l}\text { Koefisien (a) } \\
\text { Regresi (b/a) } \\
\text { Sisa }\end{array}$ & $\begin{array}{l}1 \\
1 \\
73\end{array}$ & $\begin{array}{l}20966,88 \\
127,169 \\
703,951\end{array}$ & $\begin{array}{l}20966,88 \\
127,169 \\
9,463\end{array}$ & $6,67^{*}$ & 3,37 & 6,695 \\
\hline $\begin{array}{l}\text { Tuna Cocok } \\
\text { Galat }\end{array}$ & $\begin{array}{l}23 \\
50\end{array}$ & $\begin{array}{l}205,001 \\
489,95\end{array}$ & $\begin{array}{l}8,913 \\
9,979\end{array}$ & $0,893^{\text {ns }}$ & 1,74 & 2,18 \\
\hline $\begin{aligned} & \text { Keterangan }: \\
& \quad= \text { Regresi } \\
& \text { Regresi } t \\
& \mathrm{~ns}=\text { Regresi } \\
& \mathrm{dk}= \text { derajat } \\
& \mathrm{K}=\text { Jumlah } \\
& \mathrm{KT}=\text { Kuadrat }\end{aligned}$ & ebe & $\begin{array}{l}\text { n pada } \\
\text { nifikan } \\
\text { ak linea } \\
\text { n }\end{array}$ & $\begin{array}{l}=0,05 \\
\text { da } \alpha=0 \\
h=0,893\end{array}$ & $\begin{array}{l}\left(\mathrm{F}_{\mathrm{h}}=\right. \\
\mathrm{F}_{\mathrm{t}}=1\end{array}$ & 7 & $6,695)$ \\
\hline
\end{tabular}

Untuk mengetahui keberartian persamaan regresi dilakukan uji $\mathrm{F}$, diketahui harga $\mathrm{F}_{\text {hitung }}>$ harga $\mathrm{F}_{\text {tabel }}\left(\mathrm{F}_{\mathrm{h}}=6,67>\mathrm{F}_{\mathrm{t}}=3,37\right)$, maka dapat disimpulkan, bahwa koefisien arah regresi $\mathrm{Y}$ atas $\mathrm{X}_{2}$ signifikan. Untuk uji linearitas, harga $\mathrm{F}_{\text {hitung }}=0,893<\mathrm{F}_{\text {tabe }} 1=1,74$ pada 0,05 , sehingga dikatakan regresi linear. Dengan demikian, persamaan regresi $Y=-6,139+0,221 X_{2}$ dapat digunakan untuk memprediksi hubungan variabel terikat $Y$ dengan variabel bebas $X_{2}$. Artinya untuk setiap kenaikan satu-satuan $X_{2}$, akan terjadi kenaikan terhadap $Y$ sebesar 0,221 satuan, pada $-6,139$. Kekuatan hubungan antara variabel $X_{2}$ dengan $Y$ ditunjukkan oleh koefisien korelasi $\mathrm{ry}_{3}=0,391$ dan uji keberartian koefisien kolerasi dengan uji $t$ didapat harga $t_{\text {hitung }}=4,1$. Karena $t_{\text {hitung }}=4,1>t_{\text {tabel }}=1,66$, dapat disimpulkan bahwa terdapat hubungan positif antara hasil belajar kerja bangku dengan sikap siswa SMK terhadap profesi teknisi.

Hubungan antara variabel $\mathrm{X}_{2}$ dengan $\mathrm{Y}$ ditunjukkan oleh koefisien k-relasi $\mathrm{ry}_{3}=0,391$ dan uji keberatian koefisien kolerasi dengan ujit $\mathrm{t}$ di-dapat thitung $=4,1$. Karena $t_{\text {hitung }}=4,1>t_{\text {tabel }}=1,66$ dapat disimpulkan terdapat hubungan positif antara hasil belajar kerja bangku dengan sikap siswa SMK terhadap profesi teknisi.
Koefisien determinasi antara $Y$ dengan $X_{2}$ yaitu sebesar 0,15288 . Artinya bahwa $15,288 \%$ variasi yang terjadi pada hasil belajar pengetahuan keterampilan dasar teknik dapat dijelaskan oleh sikap siswa SMK terhadap profesi teknisi.

Ketiga, hubungan antara kemampuan berpikir induktif dan sikap siswa terhadap profesi teknisi dengan hasil belajar kerja bangku diperoleh persamaan regresi $Y=-7,107+0,251 X_{1}+0,193 X_{2}$.

Tabel 3. Analisis Varians Regresi Linear jamak $Y=-7,101+0,251 X_{1}+0,193 X_{2}$

\begin{tabular}{|c|c|c|c|c|c|c|}
\hline $\begin{array}{l}\text { Sumber } \\
\text { Varians }\end{array}$ & $\mathrm{dk}$ & JK & KT & $\mathrm{F}_{\text {hitung }}$ & \multicolumn{2}{|c|}{$\mathrm{F}_{\text {tabel }}$} \\
\hline Total & 75 & 21798 & 21798 & & $(5 \%)$ & $(1 \%)$ \\
\hline $\begin{array}{l}\text { Regresi (a) } \\
\text { Regresi (b/a) } \\
\text { Sisa }\end{array}$ & $\begin{array}{l}1 \\
1 \\
73\end{array}$ & $\begin{array}{l}20966,88 \\
69,61 \\
761.51\end{array}$ & $\begin{array}{l}20966,88 \\
69,61 \\
10,432\end{array}$ & $6,67^{*}$ & 3,37 & 6,695 \\
\hline $\begin{array}{l}\text { Tuna Cocok } \\
\text { Galat }\end{array}$ & $\begin{array}{l}10 \\
63\end{array}$ & $\begin{array}{l}116,242 \\
646,07\end{array}$ & $\begin{array}{l}11,624 \\
10,242\end{array}$ & $1,135^{\text {ns }}$ & 1,98 & 2,61 \\
\hline
\end{tabular}

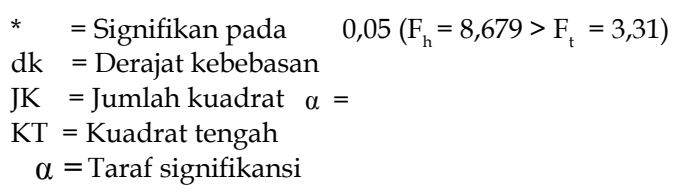

Derajat keberartian diuji dengan menggunakan uji F. Dari hasil perhitungan diperoleh $\mathrm{F}_{\text {hitung }}=8,679$ dan $\mathrm{F}_{\text {tabel }}=$ untuk $\alpha=0,05=3,13$ dan untuk $\alpha=0,01$ $=4,92$. Karena harga $F_{\text {hitung }}>F_{\text {tabel }}\left(F_{h}=8,679>F_{t}\right.$ $=3,13)$, dapat disimpulkan bahwa persamaan regresi $\mathrm{Y}=-7,107+0,251 \mathrm{X}_{1}+0,193 \mathrm{X}_{2}$ dapat digunakan untuk memprediksi kemampuan berpikir induktif, dan sikap siswa terhadap profesi teknisi dengan hasil belajar kerja bangku.

Perhitungan korelasi jamak antara variabel $\mathrm{X}_{1^{\prime}}$ dan $\mathrm{X}_{2}$, dengan $\mathrm{Y}$ menghasilkan Ry $12=0,441$. Uji keberartian koefisien korelasi dengan uji $\mathrm{F}$, diperoleh $\mathrm{F}_{\mathrm{h}}=8,674$, dan $\mathrm{F}_{\mathrm{t}}=$ pada $\alpha=0,05$ sebesar 3,31, maka dapat dinyatakan korelasi yang terjadi antara $Y$ dengan $X_{1}$, dan $X_{2^{\prime}}$ secara bersama-sama "berarti". Dengan demikian dapat disimpulkan bahwa terdapat hubungan yang positif antara kemampuan, berpikir induktif siswa SMK dan sikap siswa terhadap profesi teknisi secara bersama-sama dengan Hasil belajar kerja bangku.

Koefisien determinasi $R_{2}=0,194$. Ini menunjukkan bahwa 19,4\% variasi yang terjadi pada hasil belajar kerja bangku siswa SMK dapat diprediksi oleh kemampuan berpikir induktif, dan sikap siswa SMK terhadap profesi teknisi dengan hasil belajar kerja bangku secara bersama melalui persamaan regresi $Y=$ $-7,107+0,251 X_{1}+0,193 X_{2}$. 


\section{Implikasi}

a. Upaya Meningkatkan Berpikir Induktif

Untuk dapat lebih meningkatkan hasil belajar kerja bangku siswa SMK, maka perlu adanya upaya antara lain: pertama, sistem pembelajaran di kelas baik yang bersifat teori, maupun praktik perlu diciptakan se-demikian rupa sehingga dapat melatih kognitif siswa. Hal ini akan dapat meningkatkan pengetahuan keteram-pilan dasar teknik. Kedua, perlu memberikan pengalaman yang cukup yang dapat melatih cara berpikir siswa. Pengalaman tersebut dapat diperoleh di sekolah, di rumah atau dapat juga dengan teman sejawat. Ketiga, suasana belajar baik di laboratorium maupun di kelas perlu diciptakan sedemikian rupa, sehingga suasana belajarnya dapat mengembangkan kemampuan berpikir induktif seoptimal mungkin. Keempat, pengoptimalan kemampuan berpikir induktif dapat melalui mata pelajaran yang dapat mengembangkan hal tersebut, seperti matematika dan mata pelajaran eksakta lainnya. Kelima, Biasakan anak berdiskusi mengamati gejala-gejala yang terjadi baik di bidang keteknikan maupuan di bidang-bidang lainnya. Selanjutnya anak diminta membuat kesimpulan.

b. Upaya Meningkatkan Sikap Siswa terhadap Profesi Teknisi

Ada beberapa upaya yang perlu dilakukan antara lain, perlu adanya pengarahan dan pengertian terhadap bidang pekerjaan yang akan ditekuninya. Hal tersebut akan menjadikan pandangan yang positif terhadap bidang pekerjaannya yang akan menjadikan bidang pekerjaan disenanginya. Ini akan mem-bawa dampak orang tersebut akan belajar dan ini dapat meningkatakan pengetahuannya. Selain itu pekerjaan yang ditekuni harus dirasakan manfaatnya baik bagi yang mengerjakan maupun bagi orang lain, sehingga dirasakan kepuasan bagi profesi yang ditekuninya. Faktor-faktor itu semua akan berpengaruh terhadap kualitas peralatan yang diperbaikinya. Dengan sikap seorang teknisi tersebut, tentu seorang teknisi dengan senang hati dan dengan kesadarannya akan terus belajar untuk dapat mengikuti perkembangan ilmu pengetahuan dan teknologi, terutama yang sesuai dengan bidang pekerjaannya.

Sikap seseorang dapat berubah dan dibentuk. Aspek yang mempengaruhi pembentukan sikap an-tara lain: pengalaman langsung dengan bidang pekerjaan (objek), komunikasi sosial, dan fisiologis, informasi, keinginan, hubungan dalam kelompok, serta kepribadian seseorang. Oleh karena itu, agar seorang teknisi selalu berpandangan positif terhadap pekerjaannya, faktor-faktor tersebut perlu mendapat perhatian. Masyarakat dan pemakai jasa teknisi serta pimpinan-pimpinan di perusahaan yang memiliki tenaga teknisi harus menghargai profesi teknisi dan memberikan imbalan yang wajar atas jasa pelayanannya.

\section{PENUTUP}

\section{Kesimpulan}

Dari hasil dan pembahasan pada penelitian ini menghasilkan kesimpulan sebagai berikut: Pertama, kemampuan berpikir induktif mempunyai hubungan yang positif dan signifikan dengan hasil belajar kerja bangku. Semakin tinggi kemampuan berpikir induktif siswa, maka akan semakin tinggi pula hasil belajar kerja bangkunya. Kedua, sikap siswa SMK terhadap profesi teknisi mempunyai hubungan yang positif dan signifikan dengan hasil belajar kerja bangku. Semakin tinggi sikap siswa SMK terhadap profesi teknisi, maka akan semakin tinggi pula hasil belajar kerja bangkunya dan sebaliknya. Ketiga, apabila kemampuan berpikir induktif, dan sikap siswa SMK terhadap profesi teknisi secara bersama-sama ditingkatkan, maka hasil belajar kerja bangku akan meningkat.

\section{Saran}

Beberapa saran untuk penelitian ini antara lain: pertama, SMK dalam penerimaan siswa baru untuk mempertimbangkan mengadakan tes kemampuan berpikir, selain tes lainnya. Kedua, pihak sekolah melalui guru-guru dapat memberikan pembelajaran yang dapat mengoptimalkan kemampuan anak didiknya. Ketiga, perlu juga ditambah sarana perpustakaan atau buku-buku yang berhubungan dengan kemampuan berpikir, terutama buku-buku yang dapat meningkatkan kemampuan berpikir empirik. Keempat, workshop di sekolah juga diperlukan guna memberikan pengalaman kepada para siswa agar dapat pengalaman dengan belajar mandiri, dengan cara diberikan dan disediakan waktu pada siswa di luar jam pelajaran untuk dapat belajar sendiri di workshop. Kelima, pihak sekolah masih perlu memberikan pemahaman dan pengertian profesi yang akan dijalaninya selepas tamat sekolah. Keenam, karena kunci utama keberhasilan pembelajaran di kelas adalah guru, maka Kantor Dinas Departemen Pendidikan Nasional (Ka. Diknas) sebaiknya memberikan sarana kegiatan untuk dapat meningkatkan guru dalam menciptakan suasana belajar yang dapat menciptakan kemampuan berpikir induktif siswa.Ketujuh, perlu diadakan penelitian lanjutan tentang hasil belajar kerja bangku siswa SMK dengan memperhatikan kelemahan-kelemahan yang ada dalam penelitian. 


\section{DAFTAR PUSTAKA}

Butler, F C. (1979). Instructional system developement for vocational training. New Jersey: Englewood Cliffs.

De Bono, E. (1971). Lateral thinking for management: A Hanbook. London: Penguin Book.

Gagne, R M. (1985). The conditions oflearning and theory of instruction. New York: Holt, Rinehart and Wiston.

Gagne, R M., Briggs, L J., \& Wager, WW. (1992). Principles of instructional design. New York: Harcourt Brace Joanovich College Pub.

Larson, M E. (1972). Teaching related subject in trade and industrial and technical education. Ohio: Charles E. Merril Publishing Co.
Oskamp, S. (1977). Attitudes and opinion. New Jersey: Prentice Hall, Inc.

Parkison, G H R. (1966). An encyclopedia of philoshopy. Great Britain: Routledge.

Poepoprodjo, W. (1987). Logika scientifika. Bandung: Remaja Karya.

Schhipers, U \& Patriatna, D M. (1994). Pendidikan kejuruan di Indonesia. Bandung: Angkasa.

Suriasumantri, J S. (1998). Filsafat ilmu: Sebuah pengantar populer. Jakarta: Pustaka Sinar Harapan.

Suriasumantri, JS. (1989). Ilmu dalam perspektif. Jakarta: Yayasan Obor Indonesia.

Undang-Undang Republik Indonesia No. 20 Tahun 2003 tentang Sistem Pendidikan Nasional. Jakarta: BP Cipta Jaya. 